\title{
ТЕОРИЯ СУВЕРЕНИТЕТА ЖАНА БОДЕНА КАК ПОЛИТИКО-ФИЛОСОФСКОЕ ОБОСНОВАНИЕ КОНЦЕПЦИИ НАЦИОНАЛЬНЫХ ГОСУДАРСТВ
}

\author{
Е. В. Силина \\ Воронежский государственный университет \\ Поступила в редакцию 24 мая 2021 г.
}

\begin{abstract}
Аннотация: расслатривается теория суверенитета Жана Бодена, послужившая политико-фблособбскил обоснованиел кониепиии национальньх государств. В своих работах "Шесть книг о государстве", "Метод легкого познания истории" Боден сбборлулировал и подробно разработал понятие "суверенитет". Или были определень основнье признаки и характеристики данного понятия, Боден подчеркивал также важность наличия "суверенной власти" в государстве, которая является залогол успешного и проиветающего государства. Определяя власть правителя государства как абсолютную и полную, Боден выще этой власти ставит только Божественные законы и законы природы, которыл должны подчиняться все государи в мире. Авторол делается вывод о соотношении теории суверенитета Жана Бодена с идеологией национальньх государств, предполагающей наличие независимой и салостоятельной государственной власти как во внешней, так и во внутренней политике, за что собственно и выступает Боден в своей теории суверенитета.
\end{abstract}

Ключевые слова: суверенитет, Жан Боден, национальное государство, абсолютная власть, признаки суверенитета.

Abstract: this article examines the theory of sovereignty of Jean Bodin, which served as a political and philosophical justification for the concept of nation states. In his works "The Six Books of the Republic", "Method for the Easy Comprehension of History", Bodin formulated and developed in detail the concept of "sovereignty". He identified the main features and characteristics of this concept; Bodin also emphasized the importance of having "sovereign power" in the state, which is the key to a successful and prosperous state. Defining the power of the ruler of the state as absolute and complete, Bodin puts above this power only the Divine laws and laws of nature, to which all the sovereigns in the world must obey. The author draws a conclusion about the correlation between Jean Bodin's theory of sovereignty and the ideology of nation-states, which presupposes the existence of independent and independent state power, both in foreign and domestic policy, for which Bodin actually stands in his theory of sovereignty.

Key words: sovereignty, Jean Bodin, nation state, absolute power, characteristics of sovereignty.

Становлению национальных государств, которое активно началось после окончания Тридцатилетней войны (1618-1648) и заключения Вестфальского мира (1648), предшествовало возникновение и развитие самой идеи, понятия, сущности и признаков национальных государств. Одним из идеологов данной концепции, бесспорно, является Жан Боден (1530-

(c) Силина Е. В., 2021 
1596), который в своих работах, таких как «Шесть книг о государстве» (1576), «Метод легкого познания истории» (1566), формулирует понятие «суверенитет», его основные характеристики, придает огромное значение наличию «суверенной власти» в государстве.

Несмотря на то что данный вопрос рассматривался его предшественниками, Ж. Боден утверждает, что никто из политических философов не дал точного определения суверенитета. Сам же Боден определяет суверенитет как «верховную власть», обращаясь, однако, к терминологии своих предшественников. Он употребляет следующее понятие: summum imperium (лат. высшее командование, власть). Summum imperium - термин, использовавшийся в римском праве. В Риме власть магистратов делилась на imperium (высшая) и potestas (общая), а диктатор обладал summum imperium (высшая власть), которая помимо прочего включала право приговаривать к смертной казни, и в дальнейшем это решение нельзя было обжаловать ${ }^{1}$.

По мнению фрранцузского философа, историка Пьера Менара, теория суверенитета Ж. Бодена полностью происходит из римского права. Как довод к данному аргументу Менар указывает на то, что Ж. Боден использует латинский принцип imperium, на котором и построена его теория о свободной воле государя ${ }^{2}$. Стоит отметить, что не все ученые разделяют убеждение П. Менара о приверженности Ж. Бодена римскому праву. М. Глимор, Р. Мунье считают, что хотя Ж. Боден и использует термин «imperium», тем не менее, перечисляя характеристики суверенитета, он не приводит в качестве источников такие "памятники римского права", как Законы XII таблиц, Дигесты Юстиниана, поэтому об абсолютной приверженности его к римскому праву говорить нельзя ${ }^{3}$.

По мнению Ж. Бодена, государство берет свое начало от семьи, небольшой первоначальной ячейки общества, которая постепенно, со временем размножается и распространяется все больше, образуя в конечном счете государство. Идею происхождения государства от семьи нельзя назвать абсолютно новой. В патриархальной теории происхождения государства именно семья выступает в качестве основы для дальнейшего появления государства. Этой теории в свое время придерживались Аристотель, Конфуций Михайловский и др. ${ }^{4}$

Второй вариант: становление государства осуществляется посредством обирания изначально разрозненного народа, возможно также образование государства из колонии. Это то, что пишет Ж. Боден об учреждении государства, а само государство он определяет как осуществление

${ }^{1}$ См.: Баязитова Г. И., Митюрева Д. С. В преддверии рождения государства : язык, право и философия в политической теории Жана Бодена. Тюмень, 2012.

${ }^{2}$ Cм.: Menard P. L' essor de la philosophie politique au XVI siècle. P., 1977. P. 492. URL: https://archive.org/details/lessordelaphilos0000mens/ (дата обращения: 20.02.2021).

${ }^{3}$ Cм.: Beaulac S. The Social Pover of Bodin's "Sovereignty" and International Law // Melbourne Journal of International Law. 2017. Vol. 5. P. 48-54.

${ }^{4}$ Политология : хрестоматия / сост. М. А. Василиск, М. С. Вершинин. М., 2000. 


\section{Вестник ВГУ. Серия: Право}

суверенной властью справедливого управления многими семьями и тем, что находится в их общем владении. Ж. Боден пишет не просто об управлении кел-то государством, например монархом или даже предположим - парламентом; он акцентирует внимание на том, что государство управляется непосредственно суверенной властью, следовательно, властью независимой, неограниченной. Наличие данной суверенной власти является для Ж. Бодена определяющим признаком государства. Однако стоит обратить внимание и на то, что управление государством, по мнению Ж. Бодена, должно осуществляться на основе справедливости. Именно справедливое управление государством он называет главной целью, все это должно быть направленно на достижение высшего блага отдельного человека, что идентично высшему благу государства. Все государства учреждаются либо по принуждению сильнейших, либо на основе соглашения одних людей добровольно передать в распоряжение других людей свою свободу. По мнению Ж . Бодена, единственно, что может стоять над суверенной властью, чему должен подчиняться любой правитель - это законы Бога и природы. Божественные законы должны соблюдать и чтить правители во всем мире, они не должны идти против божественных установлений, которые по определению выше их земного суверенитета. Но во всем остальном суверенитет не может иметь никаких ограничений. Если суверенитет государя основывается на каких-то условиях или обязательствах, тогда он попросту таковым считаться не может. Подчинение законам Бога и природы не наносит никакого ущерба суверенитету государя, это, наоборот, является его обязанностью, в то время как подчинение повелениям других людей наносит существенный урон суверенитету, что является недопустимым. По мнению Ж. Бодена, не стоит удивляться тому, что добродетельных государей мало, поскольку таких ๓ людей вообще мало, и из их числа правители избираются крайне редко.

이 Факт существования в мире хороших государей Ж. Боден называет как «великое диво» или «чудо». В своей работе «Шесть книг о государстве» он говорит также о необходимости наличия частной собственности у граждан государства и критикует Платона и его идею общей собственности ${ }^{5}$.

В десятой главе первой книги о государстве Ж. Боден перечисляет

102 пять основных признаков суверенитета, которые он называет «истинными отличиями суверенитета»:

1. Назначение магистратов и определение их обязанностей и полномочий.

2. Принятие, отмена и обнародование законов.

3. Объявление войны и заключение мира.

4. Высшая судебная инстанция как для магистратов, так и для граждан.

5. Право помилования.

Он подробно поясняет значение и сущность каждого признака.

5 Cm.: Bodin J. Les six livres de la Republique. URL: http:/gallica.bnf.fr/ ark:/121448/btv1b86268103/ (дата обращения: 16.02.2021). 
Рассматривая первый признак, приведем один интересный пример. В своей книге «Метод легкого познания истории» Ж. Боден рассуждает на тему, должны ли иметь магистраты так называемое gladii potestas (право меча) или же это является исключительной прерогативой государя. Право меча, по Бодену, - это право на жизнь и смерть своих подданных в случае необходимости. В качестве примера он приводит спор юрисконсульта Ацо и Лотаря. Ацо выступает за возможность магистратов обладать правом меча, а Лотарь против. В данном случае Ж. Боден полностью поддерживает Лотаря, хотя и отмечает, что все-таки большинство ученых-правоведов будут согласны с мнением Ацо ${ }^{6}$. Данный пример можно отнести не только к первому признаку, но и к четвертому, где говорится о том, что именно государь является высшей судебной инстанцией как для самих магистратов, так и для граждан, т. е. именно правитель будет решать окончательную судьбу своих подданных, а не магистрат. Магистраты подчиняются государю, который возглавляет данную иерархическую цепочку.

Второй признак касается принятия и отмены законов, и этим правом снова обладает только лишь суверенный правитель, здесь можно видеть явное проявление «абсолютной власти», сторонником которой выступал Ж. Боден. Законы в государстве не принимаются с согласия Сената или какого-либо другого государственного органа, принятие законов осуществляется правителем единолично и по своему усмотрению. Конечно, с современным порядком принятия законов идея, предложенная Ж. Боденом, ничего общего не имеет.

Третий признак - объявление войны и заключение мира - связан с военной безопасностью страны и защитой ее от внешних врагов. Признак, по мнению Ж. Бодена, важный, так как принятие данных решений может повлечь за собой разрушение или, наоборот, защиту и процветание государства.

Четвертый признак касается высшей судебной инстанции, т. е. магистраты наделены полномочиями по осуществлению правосудия (хотя опять же этими полномочиями их наделил именно суверенный правитель), но они действуют исключительно в рамках закона (который был принят государем) и не имеют права толковать и интерпретировать его по-своему, в то время как сам правитель может изменить закон и скорректировать судебное решение по своему усмотрению.

Пятым признаком суверенитета является право помилования. Ж. Боден пишет: «Это наиболее высокий признак суверенитета, присущий Величию». Проводя параллель с современностью в соответствии со ст. 89 Конституции РФ, право помилования осужденных лиц принадлежит Президенту РФ, такой же порядок предусмотрен и в большинстве зарубежных стран, например США, Франции, Германии и др.

${ }^{6}$ См.: Боден Ж. Метод легкого познания истории / под ред. М. С. Бобковой. М., 2000 . 
«Суверенитет - это абсолютная и постоянная власть...», - пишет Ж. Боден в «Шести книгах о государстве» ${ }^{7}$. Постоянство власти означает, что она не должна быть ограничена никакими временными промежутками. Ж. Боден считает, что государь должен править непосредственно с момента вступления в должность и до своей естественной смерти. К этому же вопросу можно отнести и его рассуждения по поводу регентов и их полномочий. В 1407 г. королем Франции Карлом VI был опубликован приказ, касающийся регентства, из которого следовало, что регент хотя и получает определенные полномочия, но королевским авторитетом он все же не располагает, так как он (авторитет) неотделим от короля. Боден полагает, что регент не является носителем суверенитета, он становится лишь временно исполняющим обязанности того, кому поистине принадлежит верховная власть. О такой характеристике, как абсолютность, мы говорили выше, когда речь шла о признаках ${ }^{8}$.

Что же касается форм правления, то Ж. Боден выделяет всего лишь три формы: демократию, аристократию и монархию, которые различаются принадлежностью суверенной власти. При демократии суверенной властью обладает большая часть граждан, при аристократии - меньшая часть, а при монархии власть принадлежит одному лицу. $К$ демократии и аристократии Ж. Боден относится отрицательно. Лучшей формой правления, по его мнению, является монархия, так как она прямо отвечает природе суверенной власти: ее единству и неделимости.

Политико-философркое обоснование концепции национальных государств, наряду с Ж. Боденом, было также дано итальянским философским и политическим деятелем Николо Макиавелли, который создал такие произведения, как «Государь» (1513), «Рассуждения о первой декаде Тита Ливия» (1516). В этих работах он пишет о сильном и независимом государстве, разделении светской и религиозной мысли, а также о важности патриотизма и др. ${ }^{9}$ Тем не менее в своих работах Ж. Боден подвергает критике Н. Макиавелли. Говоря о необходимости наличия у государя постоянной и абсолютной власти, называя его "верховным правителем», Ж. Боден все же ставит над ним Божественные законы и законы природы, которые каждый правитель, каким бы великим он ни был, обязан соблюдать. Ж. Боден, критикуя Н. Макиавелли, пишет в предисловии к «Шести книгам о государстве», что «...по Макиавелли, существует всего лишь два основания Республик: безбожие и несправедливость. Порицание религии и возвеличивание государства и тиранических правителей, освобожденных от любых моральных принципов». Образ идеального правителя, описанный Н. Макиавелли в «Государе», представляется Ж. Бодену полной противоположностью его собственного представления о государе. Хотя взгляды Ж. Бодена и Н. Макиавелли на то, каким долж-

${ }^{7}$ Cм.: Bodin J. Les six livres de la Republique. URL: http://gallica.bnf.fr/ ark:/121448/btv1b86268103/ (дата обращения: 16.02.2021).

${ }^{8}$ Cм.: Andrew E. Jean Bodin on Sovereignty // Political Theory. 2021. Vol. 2. P. 126-133.

${ }^{9}$ См.: Макиавелли Н. Государь. М., 2019. 
но быть идеальное государство и его правитель, по заявлениям самого Ж. Бодена, кардинально различались, тем не менее оба философа являются идеологами концепции национальных государств ${ }^{10}$.

Таким образом, по Ж. Бодену, суверенитет - абсолютная и постоянная власть в одной республике. Правитель, обладающий суверенитетом, принимает и отменяет законы, объявляет войну и заключает мир, является высшей судебной инстанцией для всех магистратов и граждан, имеет право карать и миловать, назначает магистратов и определяет их служебные обязанности. Сам государь не подчиняется ничьей воле, он не ограничен никакими законами, он не сменяем, правит с момента вступления в должность и до своей естественной смерти. Единственное, что он должен неукоснительно соблюдать и чтить - это Божественные законы и законы природы. Теория суверенитета Ж. Бодена является политико-философрским обоснованием концепции национальных государств, ведь национальное государство предполагает наличие независимой и самостоятельной государственной власти не только во внутренней, но и во внешней политике. В своей теории суверенитета Ж. Боден говорит именно о такой власти. По его мнению, если происходит вмешательство в дела правителя, принимаемые им решения, то такая власть «суверенной» не является вовсе. Ж. Боден выступает за сильную, независимую власть.

\section{Библиографический список}

Баязитова Г. И. Жан Боден. «Шесть книг о государстве». Предисловие : перевод и комментарии // Европа. 2014. № 13. С. 225-229.

Баязитова Г. И., Митюрева Д. С. В преддверии рождения государства : язык, право и философия в политической теории Жана Бодена. Тюмень : Изд-во Тюменского гос. ун-та, 2012. 239 с.

Боден Ж. Метод легкого познания истории / под ред. М. С. Бобковой. М. : Наука, 2000. 214 с.

Макиавелли Н. Государь. М. : АСТ, 2019. 416 с.

Политология : хрестоматия / сост. М. А. Василиск, М. С. Вершинин. М. : Гардарики, 2000. 843 с.

Andrew E. Jean Bodin on Sovereignty // Political Theory. 2021. Vol. 2. P. 126-133.

Beaulac S. The Social Pover of Bodin's "Sovereignty" and International Law // Melbourne Journal of International Law. 2017. Vol. 5. P. 48-54.

Bodin J.Les six livres de la Republique. URL: http://gallica.bnf.fr/ark:/121448/ btv1b86268103/

Menard P. L' essor de la philosophie politique au XVI siècle. P., 1977. P. 492. URL: https://archive.org/details/lessordelaphilos0000mens/

\section{References}

Bayazitova G. I. Jean Boden. "Six books about the state". Foreword: translation and comments // Europe. 2014. № 13. P. 225-229.

${ }^{10}$ См.: Баязитова Г. И. Жан Боден. «Шесть книг о государстве». Предисловие : перевод и комментарии // Европа. 2014. № 13. С. 225-229. 
Bayazitova G. I., Mityureva D. S. On the eve of the birth of the state: language, law and philosophy in the political theory of Jean Boden. Tyumen : Publishing House of Tyumen State University, 2012. 239 p.

Boden J. Method of easy cognition of history / Ed. M. S. Bobkova. M. : Nauka, 2000. 214 p.

Machiavelli N. Sovereign. M. : AST, 2019. 416 p.

Politology: a reader / Comp. M. A. Vasilisk, M. S. Vershinin. M. : Gardariki, 2000. $843 \mathrm{p}$.

Andrew E. Jean Bodin on Sovereignty // Political Theory. 2021. Vol. 2. P. 126-133.

Beaulac S. The Social Pover of Bodin's "Sovereignty" and International Law // Melbourne Journal of International Law. 2017. Vol. 5. P. 48-54.

Bodin J. Les six livres de la Republique. URL:http://gallica.bnf.fr/ark:/121448/ btv1b86268103/

Menard P. L' essor de la philosophie politique au XVI siècle. P., 1977. P. 492. URL: https://archive.org/details/lessordelaphilos0000mens/

\section{Для иитирования:}

Силина E. В. Теория суверенитета Жана Бодена как политико-философское обоснование концепции национальных государств // Вестник Воронежского государственного университета. Серия: Право. 2021. № 3 (46). C. 100-106. DOI: https://doi. org/10.17308/vsu.proc.law.2021.3/3543

\section{Recommended citation:}

Silina $E$. V. Jean bodin's theory of sovereignty as a political and philosophical justification of the concept of nation-states // Proceedings of Voronezh State University. Series: Law. 2021. № 3 (46). P. 100-106. DOI: https://doi.org/10.17308/vsu.proc.law.2021.3/3543

Воронежский государственньй университет

Силина Е. В., аспирант кафбедры теории и истории государства и права

E-mail:ekaterina_sil@mail.ru

\section{Voronezh State University}

Silina E. V., Post-graduate Student of the Theory and History of State and Law Department

E-mail: ekaterina_sil@mail.ru 